\title{
12 TIPS MANAJEMEN SUMBER DAYA MANUSIA YANG EFEKTIF
}

\author{
Khalimatus Sakdiyah \\ Universitas Muhammadiyah Sidoarjo \\ sakhrnijad@tutanota.com
}

Sebuah bisnis tidak dapat berkembang tanpa staf yang dapat diandalkan, jadi terlepas dari seberapa kecil bisnis Anda, sumber daya manusia (SDM) atau Human Resources (HR) akan tetap menjadi bagian penting dari perjalanan Anda menuju sukses. Berikut adalah 12 kiat sumber daya manusia bisnis terbaik dari para profesional.

\section{Hindari Pelanggaran Lembur}

Pemilik bisnis yang sangat kecil sering melakukan semuanya sendiri, termasuk SDM. Jika ini melibatkan undang-undang ketenagakerjaan, pemberi kerja harus menyadari praktik terbaik. Upah dan jam utama yang perlu diingat adalah: tahu bagaimana lembur terakumulasi, sadar akan undang-undang negara bagian, mengklasifikasikan karyawan dengan benar, melacak waktu untuk karyawan per jam, dan membayar karyawan untuk semua waktu kerja. Hukuman untuk melanggar hukum lembur bisa sangat mahal dan Kementerian Tenaga Kerja secara rutin melakukan penyelidikan. Untuk melindungi diri Anda, 
tetap berpegang pada aturan dan menyimpan catatan akurat.

\section{Jadilah fleksibel}

Pertama, cukup ingin tahu untuk menemukan apa yang tidak Anda ketahui. Sangat mudah untuk melakukan hal-hal yang kami nyamankan, tetapi Anda perlu belajar tentang hal-hal baru yang terjadi sebagai akibat dari langkah dan volume perubahan di seluruh industri dan profesi Anda. Alokasikan waktu baik online maupun melalui jaringan untuk mengungkap isu-isu baru dan praktik terbaik yang disarankan orang lain untuk mengatasinya. Pertimbangkan mensponsori pertemuan kelompok bisnis dan industri di situs perusahaan Anda untuk memungkinkan staf Anda berinteraksi dengan orang lain.

Kedua, cobalah hal-hal baru. Perubahan dunia dan kebijakan statis yang Anda gunakan di masa lalu sering kali perlu diperbarui. Berapa banyak dari kita yang memiliki buku panduan yang mengandung bahasa "sesuka hati"? Bukankah itu ketinggalan jaman (sungguh, kapan terakhir kali kamu memecat seseorang tanpa alasan)? Demikian juga, arbitrase wajib: Pernah bertanya-tanya mengapa ada begitu banyak tuntutan hukum? Kami kebanyakan melakukan apa yang telah dilakukan sebelumnya, tetapi terkadang ada cara yang lebih baik, dan siapa yang lebih baik menyarankan hal-hal tersebut daripada SDM?. 


\section{Siapkan Proses Umpan Balik yang Sehat}

Luangkan waktu untuk menyiapkan proses umpan balik bagi karyawan perusahaan Anda. Umpan balik sangat penting untuk pertumbuhan karyawan individu serta pertumbuhan perusahaan Anda. Agar karyawan tetap terlibat, petugas SDM dapat mendorong kepemimpinan untuk memberikan umpan balik konstruktif yang dipersonalisasi kepada karyawan, baik positif maupun negatif. Jika karyawan meluangkan waktu untuk mengembangkan pekerjaan berkualitas tinggi, terserah kepada para manajer dan pemimpin untuk mengenali upaya dan keberhasilan mereka. Kita telah menemukan bahwa catatan tulisan tangan sederhana, email, atau bahkan secangkir kopi untuk mengucapkan selamat kepada tim atas pekerjaan yang dilakukan dengan baik sangat bagus untuk semangat kerja dan mendorong mereka untuk tetap bekerja dengan baik.

\section{Memahami angka-angka}

Ingin sesuatu yang membutuhkan uang? Ini semua tentang anggaran dan tabungan, dan Anda harus berjuang untuk apa yang Anda butuhkan. Para pemimpin SDM sering ragu-ragu untuk mengusulkan program karena mereka takut ini tidak akan pernah disetujui. Kita pernah mengusulkan membuat sistem pelamar pemohon baru dan memiliki pelamar menggunakan 100 komputer di pusat perekrutan untuk memasukkan data mereka sendiri secara langsung. 
Biayanya tinggi, tetapi kita bisa menunjukkan laba atas investasi yang cukup disimpan dalam dua tahun untuk membayarnya kembali. Seandainya kita tidak memahami perlunya, dan metodologi, pengembalian standar analisis investasi, upaya ini tidak akan pernah disetujui. Kita semua hidup dengan anggaran, tetapi itu tidak berarti Anda harus menyerah tanpa menggunakan semua alat yang tersedia untuk berdebat secara efektif untuk ide-ide Anda.

\section{Ketahuilah Hukum}

Penting untuk memahami undang-undang RI ketika menyangkut karyawan Anda. Fungsi dasar seperti keselamatan dan keamanan, praktik perekrutan, kompensasi dan tunjangan yang dibutuhkan, jadwal kerja, waktu liburan, dan waktu cuti adalah pertanyaan berputar-putar untuk pemilik usaha kecil. Tempat yang baik untuk memulai adalah dengan mengacu pada regulasi dari Kementerian tenaga kerja RI. Setelah Anda membiasakan diri dengan hukum dan peraturan ini, Anda siap untuk pindah ke area fokus berikutnya.

\section{Jadilah mitra lengkap}

Kita sering mendengar bahwa HR menginginkan tempat duduk di "meja." Tebak apa? Kamu harus mendapatkannya. Itu berarti orang melihat Anda sebagai pemikir yang jernih, pemimpin yang baik dan orang bisnis yang cerdas, yang 
semuanya dibutuhkan untuk menjadi sukses dalam karier Anda.

Berkolaborasi dengan masing-masing kepala departemen secara individual untuk mempelajari apa kebutuhan mereka dan apa yang mereka harapkan dari SDM. Kolaborasi adalah cara terbaik untuk mendapatkan ide dan praktik SDM yang diterima dan diterapkan di organisasi Anda.

Luangkan waktu untuk bekerja di setiap departemen, lakukan kelompok fokus, jalankan program uji coba untuk menilai penerimaan dan kegunaan ide-ide Anda, dan mulai kelompok penasihat untuk memberikan masukan bagi proses perencanaan Anda.

Tunjuk manajer pelatihan departemen, pengawas jalur yang mengambil tanggung jawab untuk menentukan pelatihan apa yang diperlukan di area mereka, serta kapan dan bagaimana pelatihan harus disajikan, dan memantau kehadiran dan kinerja dan perilaku pasca pelatihan.

\section{Abaikan Mitos Mengenai Milenium}

Kita pernah berpikir salah satu hal paling cerdas yang kita dengar dalam beberapa tahun terakhir mengenai praktik SDM adalah menyadari bagaimana Anda bersandar pada mitos tentang Millennial di tempat kerja. Kita telah bekerja hampir secara eksklusif dengan Millennial sebagai staf kita, dan menemukan setiap orang yang sangat berdedikasi 
untuk pekerjaan mereka, bersemangat untuk belajar, penuh ide-ide cemerlang, dan tidak takut untuk membagikannya. Itu hal yang bagus. Aturan praktis yang mudah: jika Anda dapat menukar "Milenium" di salah satu pernyataan ini untuk nama grup terpinggirkan lainnya dan kedengarannya buruk, jangan katakan itu. Juga sadar, apakah Anda menyadarinya atau tidak, banyak stereotip Millenial secara khusus ditujukan untuk wanita muda (yang suka terbang, mengambil selfie, menjadi tren sembrono). Generalisasi semacam ini dapat dengan mudah tumpang tindih dengan (atau mengarah pada) perilaku seksis atau melecehkan di antara staf Anda, jika tidak hati-hati.

\section{Keluar dari kantor Anda}

Berada jauh dari kantor Anda lebih dari yang ada di dalamnya. Karyawan sering berpikir untuk pergi ke HR sama seperti pergi ke kantor kepala sekolah. Tidak demikian halnya jika Anda adalah pemimpin SDM yang sering mengunjungi tempattempat kerja karyawan Anda. Mereka akan menjadi akrab dengan Anda dan lebih terbuka untuk mengajukan pertanyaan, dan Anda akan menjadi lebih akrab dengan konteks masalah yang harus Anda tangani.

Karyawan akan menghargai kehadiran Anda dan manajer akan merasa lebih nyaman dengan ide-ide Anda. Anda akan segera terlihat sebagai bagian dari 
tim alih-alih orang SDM yang bersembunyi di balik kebijakan tersebut. Ini memberi peluang kepada HR untuk menangani masalah sebelum menjadi masalah besar.

\section{Rekrut Karyawan Baru dengan Karyawan Saat Ini}

Adalah bijaksana untuk melakukan segala kemungkinan untuk menurunkan risiko gesekan, dan meningkatkan peluang bahwa karyawan baru Anda akan menemukan kebahagiaan abadi di tempat kerja baru mereka. Studi menunjukkan bahwa hal nomor satu yang dapat kita lakukan untuk meningkatkan secara substansial karyawan baru yang mencuatkannya selama beberapa bulan pertama pekerjaan yang diprediksi menantang adalah dengan meminta mereka menjalin hubungan dengan seseorang di dalam perusahaan, bahwa mereka akan nyaman dengan pertanyaan, dan untuk saran. Orang ini tidak harus menjadi laporan langsung mereka. Bahkan, bisa menjadi rekan, atau manajer satu tingkat di atas mereka, di departemen lain.

\section{Ambil risiko}

Sebagian besar profesional SDM menghindari risiko, mungkin karena mereka tidak didorong (atau dipercaya) untuk mengambil risiko. Tetapi praktisi yang sukses memahami kebutuhan untuk mengambil peluang dan nilai yang dapat dihasilkan. Kami juga 
menjangkau orang-orang yang tidak pernah berpikir mereka memiliki kesempatan untuk bekerja di perusahaan kasino besar - bukan karena kami membutuhkan lebih banyak pelamar, tetapi karena itu adalah hal yang benar untuk dilakukan.

\section{Simpan Dokumentasi yang Tepat dari File Personil}

Tindakan SDM yang paling efektif dapat dilakukan dalam bisnis kecil, adalah mendigitalkan dan memusatkan file personel mereka. Begitu banyak perusahaan kecil membuat kesalahan dengan 'membuat' dengan file dan spreadsheet kertas, tetapi itu menyebabkan mimpi buruk ketika saatnya tiba untuk memperluas tenaga kerja. Jika Anda masuk ke dalam kebiasaan praktik terbaik untuk memelihara database SDM digital terpusat, Anda akan memiliki landasan yang sangat baik untuk pertumbuhan perusahaan. Dan jika Anda memilih sistem SDM yang tepat untuk membantu Anda, Anda akan mendapatkan nilai yang jauh lebih besar daripada hanya akses mudah ke catatan karyawan dan kebijakan perusahaan - Anda akan menikmati proses perekrutan yang efisien melalui ATS (Applicant Tracking System), tinjauan kinerja akan konsisten, dan data SDM akan lebih mudah dianalisis. 


\section{Menginspirasi yang lain}

Kata yang paling sering kita gunakan untuk menggambarkan gaya SDM kita adalah inspirasional. Profesional SDM mewakili "aturan," dan terlalu sering kita dilihat sebagai teknokrat atau pemenang kebijakan, entah bagaimana terputus dari dunia nyata kebutuhan organisasi. Yang pasti ada dalam pekerjaan, tetapi semakin Anda menginspirasi orang lain untuk memahami bagaimana dan mengapa SDM diperlukan, dan bagaimana kita dapat bekerja untuk keuntungan mereka, semakin Anda akan menjadi pemimpin yang diakui dalam organisasi Anda. Jika Anda memiliki gairah, akan ada gairah dalam budaya perusahaan Anda. Jika tidak, itu hanya akan menjadi pekerjaan lain untuk Anda dan mereka yang bekerja untuk organisasi Anda. Itu tidak menyenangkan, dan itu bukan jenis kepemimpinan yang dibutuhkan dari profesional HR saat ini.

\section{Reference}

Dizon, A. (2018). 32 Small Business Human Resource (HR) Tips From the Pros. Retrieved April 15, 2018, from https://fitsmallbusiness.com/humanresource-tips-hr/

KBBI. (2017). Sumber. Retrieved April 30, 2018, from https://kbbi.web.id/sumber

Lambert, T. (2016). Tips for Managers - Effective Human Resource Management. Retrieved April 20, 2018, from

http://carterlambert.com.au/effective-human- 
resource-tips/

Nathan, A. (2015). 10 Things Every HR Professional

Needs to Do to Succeed. Retrieved April 19,

2018, from https://www.shrm.org/hr-

today/news/hr-news/pages/arte-nathan-hr-

success-tips.aspx

Purnomo, A., Putri, R. A., \& Rosyidah, E. (2017).

Kamus Manajemen Sumber Daya Manusia.

Sidoarjo: UNUSIDA Press. 